\title{
Kebutuhan perawatan ortodonsi berdasarkan index of orthodontic treatment need pada siswa usia 12-13 tahun di SMP Negeri 1 Wori
}

\author{
${ }^{1}$ Fanessa E. Kolonio \\ ${ }^{2}$ P. S. Anindita \\ ${ }^{2}$ Christy N. Mintjelungan
}

\author{
${ }^{1}$ Kandidat Skripsi Program Studi Pendidikan Dokter Gigi Fakultas Kedokteran \\ ${ }^{2}$ Program Studi Pendidikan Dokter Gigi Fakultas Kedokteran \\ Universitas Sam Ratulangi Manado \\ Email: fanessakolonio@yahoo.com
}

\begin{abstract}
Malocclusion is a form of occlusal disorders caused by irregular teeth growthas well as sizes and position of teeth. Malocclusion could create some disturbances in both physical and mental health of a person including problems in oral function, mastication, highly risk of trauma, periodontal diseases, and caries. Esthetically, malocclusion could affect a person's appearances and psychological development especially in adolescent. Orthodontic treatment is performed to fix the malocclusion that could affect one's oral health. The needs of orthodontic treatment itself can be leveled by using Index of Orthodontic Treatment Need (IOTN). This study was aimed to obtain the needs of orthodontic treatment based on IOTN among students aged 12-13 years old at SMPN 1 Wori. This was an observational descriptive study with a cross sectional design. There were 30 respondents obtained by using purposive sampling technique. The need of treatment was leveled by using IOTN consisted of two components: aesthetic component (AC) and dental health component (DHC). The needs of orthodontic treatment measured with AC, 27 person (90\%) were as follows: no need or little need for treatment in 27 students $(90 \%)$; borderline need in 2 students (6.7\%); and treatment required in 1 student $(3.3 \%)$. The needs of orthodontic treatment based on DHC were as follows: no need or little need for treatment in 18 students $(60 \%)$; borderline need in 8 students $(26.7 \%)$; and treatment required in 4 students $(13.3 \%)$.
\end{abstract}

Keywords: malocclusion, needs of orthodontic treatment, IOTN.

\begin{abstract}
Abstrak: Maloklusi merupakan penyimpangan oklusi akibat tidak teraturnya pertumbuhan, posisi, serta ukuran gigi. Maloklusi dapat menyebabkan gangguan kesehatan fisik dan psikis, antara lain dapat mengganggu fungsi oral, mastikasi, berisiko tinggi terhadap trauma, penyakit periodontal, dan karies. Maloklusi secara estetis juga dapat memengaruhi penampilan wajah seseorang dan perkembangan psikologis terutama pada remaja. Perawatan ortodonsi ditujukan untuk memperbaiki maloklusi yang dapat memengaruhi kesehatan gigi dan rongga mulut. Perawatan ortodonsi yang tepat dapat dilihat dari tingkat kebutuhan perawatan ortodonsi yang diukur dengan Index of Orthodontic Treatment Need (IOTN). Penelitian ini bertujuan untuk mengetahui kebutuhan perawatan ortodonsi berdasarkan IOTN pada siswa berusia $12-13$ tahun di SMP N 1 Wori. Jenis penelitian ialah deskriptif observasional dengan desain potong lintang. Subjek penelitian berjumlah 30 siswa diperoleh dengan teknik purposive sampling. Kebutuhan perawatan ortodonsi menggunakan Index of Orthodontic Treatment Need (IOTN) dengan dua komponen, yaitu Aesthetic Component (AC) dan Dental Health Component (DHC). Kebutuhan perawatan ortodonsi berdasarkan AC yaitu: 27 orang (90\%) tidak atau butuh perawatan ringan; 2 orang $(6,7 \%)$ perawatan borderline; dan 1 orang $(3,3 \%)$ sangat butuh perawatan. Kebutuhan perawatan ortodonsi berdasarkan DHC yaitu: 18 orang $(60 \%)$ tidak atau butuh perawatan ringan; 8 orang $(26,7 \%)$ perawatan borderline, dan 4 orang $(13,3 \%)$ sangat butuh perawatan.
\end{abstract}

Kata kunci: maloklusi, kebutuhan perawatan, IOTN 
Maloklusi merupakan penyimpangan oklusi akibat tidak teraturnya pertumbuhan dan posisi serta ukuran gigi. ${ }^{1}$ Maloklusi dapat menyebabkan gangguan kesehatan fisik dan psikis, antara lain menggangu fungsi oral, mastikasi, berisiko tinggi terhadap trauma, penyakit periodontal, karies, dan estetis. $^{2}$ Penelitian di Inggris menunjukan bahwa karies gigi dan penyakit periodontal dapat disebabkan oleh maloklusi. Kondisi gigi geligi yang tidak teratur menyulitkan aksi pembersihan gigi dengan sikat gigi yang memicu akumulasi plak. ${ }^{3}$ Maloklusi secara estetis juga dapat memengaruhi penampilan wajah seseorang dan perkembangan psikologis terutama pada usia remaja. ${ }^{4}$ Di Indonesia prevalensi maloklusi tahun 2006 pada remaja mencapai $89 \%$. $^{2}$

Maloklusi dapat diperbaiki dengan perawatan ortodonsi. Perawatan ortodonsi telah direkomendasikan untuk meningkatkan kemampuan fungsi oral dan bicara. Dewasa ini perawatan ortodonsi semakin banyak dilakukan untuk alasan estetis yaitu memperbaiki penampilan seseorang. Penentuan tingkat keberhasian perawatan ortodonsi dapat diidentifikasi dari tingkat kebutuhan perawatan ortodonsi yang dapat diukur dengan Index of Orthodontic Treatment Need (IOTN). ${ }^{2}$

Index of Orthodontic Treatment Need (IOTN) merupakan salah satu indeks yang menggambarkan kebutuhan perawatan ortodonsi pada suatu populasi. ${ }^{5}$ Penilaian kebutuhan perawatan ortodonsi berdasarkan IOTN telah disepakati secara internasional karena metode ini terbukti valid dan dapat dipercaya untuk menjadi standar penilaian terhadap kebutuhan perawatan ortodonsi. ${ }^{6}$ IOTN memiliki dua komponen, yaitu Aesthetic Component (AC) dan Dental Health Component (DHC). Aesthetic component menilai persepsi tentang penampilan gigi-geligi melalui sebuah skala fotograf dimana terdapat 10 poin dari tingkatan estetis paling menarik sampai paling tidak menarik. Dental Health Component menilai beberapa jenis maloklusi seperti: openbite, overbite, overjet, crossbite, crowding, erupsi terhalang, anomali palatal dan bibir, serta hipodonsia. ${ }^{7}$

Penelitian terdahulu mengenai tingkat kebutuhan perawatan ortodonsi dengan menggunakan IOTN telah dilakukan di negara-negara Eropa seperti Spanyol, Inggris, Prancis, Itali, Swedia dan di Indonesia antara lain oleh di Bandung ${ }^{8}$ dan Jakarta. $^{9}$ Penelitian oleh Musyulianti ${ }^{10}$ (2010) terhadap siswa-siswa di SMP Eben Heazer mendapatkan kebutuhan perawatan orto-donsi bekisar 3-28\%. Penelitian serupa oleh Endang ${ }^{11}$ (2011) pada siswa SMA di Kecamatan Malalayang mendapat-kan 5$17 \%$ membutuhkan perawatan ortodonsi. Penelitian yang serupa dilakukan di Sekolah Menengah Pertama Negeri 2 Bitung oleh Monica ${ }^{12}$ (2014), dengan hasil 5-8\% membutuhkan perawatan ortodonsi.

Pada umumnya prevalensi maloklusi usia remaja cukup tinggi. ${ }^{13}$ Di Iran pada tahun 2007 prevalensi maloklusi pada usia 12-13 tahun cukup tinggi yaitu $83,4 \% .{ }^{14} \mathrm{Di}$ Indonesia hasil penelitian tentang maloklusi pada remaja usia 12-14 tahun mendapatkan hasil $83,3 \% .^{15}$

Penelitian ini bertujuan untuk mendapatkan tingkat kebutuhan perawatan ortodonsi pada siswa/i berusia 12-13 tahun di SMP Negeri 1 Wori Kabupaten Minahasa Utara karena sampai pada saat ini belum tersedia data statistik di Minahasa Utara mengenai tingkat kebutuhan perawatan ortodonsi.

\section{BAHAN DAN METODE PENELITIAN}

Penelitian ini dilakukan di Sekolah Menengah Pertama Negeri 1 Wori pada bulan September-Oktober 2016. Populasi penelitian ini ialah siswa-siswi berusia 12 13 tahun yang berjumlah 177 siswa. Metode pengambilan sampel yang digunakan dalam penelitian ini ialah purposive sampling dan yang memenuhi kriteria inklusi berjumlah 30 siswaorang.

Pengukuran AC diperoleh dengan mengambil foto keadaan gigi anterior subjek penelitian menggunakan kamera, sedangkan untuk pengukuran DHC dilakukan dengan pemeriksaan pada model studi dari subjek penelitian. Data sekunder meliputi data jumlah siswa dan data sosial 
ekonomi orang tua siswa yang diperoleh dari sekolah. Data disajikan dalam bentuk tabel berdasarkan jenis kelamin, AC dan DHC kemudian dianalisis berdasarkan hasil persentase.

\section{HASIL PENELITIAN}

Tabel 1 dan Tabel 2 memperlihatkan karakteristik subjek penelitian.

Tabel 1. Distribusi karakteristik subjek penelitian berdasarkan jenis kelamin

\begin{tabular}{ccc}
\hline Jenis kelamin & n & $\mathbf{( \% )}$ \\
\hline Laki-laki & 7 & 23,4 \\
Perempuan & 23 & 76,6 \\
Jumlah & 30 & 100 \\
\hline
\end{tabular}

Tabel 2. Distribusi karakteristik subjek penelitian berdasarkan usia

\begin{tabular}{ccc}
\hline Usia & $\mathbf{n}$ & $\mathbf{( \% )}$ \\
\hline 12 tahun & 13 & 43,4 \\
13 tahun & 17 & 56,6 \\
Jumlah & 30 & 100 \\
\hline
\end{tabular}

\section{BAHASAN}

Berdasarkan hasil penelitian ini, pada AC menunjukkan sebagian besar (90\%) dari subjek yang terdapat pada kategori tidak butuh perawatan atau butuh perawatan ringan yaitu sebanyak 27 orang. Hasil ini tidak jauh berbeda dengan hasil penelitian oleh Musyulianti ${ }^{10}$ pada siswasiswi SMP di Kota Manado dengan tidak butuh perawatan atau butuh perawatan ringan sebagai nilai terbanyak. Penelitian yang dilakukan oleh Wilar ${ }^{16}$ di Tareran pada siswa SMP menunjukkan hasil yang serupa yaitu jumlah subjek penelitian terbanyak pada kategori tidak butuh perawatan atau butuh perawatan ringan. Hal tersebut mungkin disebabkan oleh adanya kesamaan seperti usia subjek penelitian. Usia 12-13 tahun merupakan tahap erupsi seluruh gigi permanen. Tahap tersebut akan menunjukkan keadaan normal oklusi. ${ }^{17}$

Peneliti berasumsi bahwa keadaan tersebut dapat disebabkan oleh tingkat kesadaran orang tua dalam memberikan didikan pada anaknya untuk tidak melakukan kebiasaan buruk seperti menghisap jari. ${ }^{18}$

Kelompok yang tidak butuh perawatan atau butuh perawatan ringan merupakan kelompok terbanyak tetapi tidak berarti bahwa mereka yang termasuk dalam kelompok ini sudah memiliki susunan gigi geligi yang paling menarik. Hal ini dapat terlihat dari sebagian subjek penelitian $(50 \%)$ terdapat pada nilai 3 . Pada nilai 3 terlihat ada openbite anterior dan gigi kaninus sedikit ektopik pada rahang atas namun pada rahang bawah terlihat normal. Kaninus ektopik merupakan kelainan dalam rongga mulut yang dapat terjadi di rahang atas dan atau rahang bawah. Gigi ektopik dapat disebabkan oleh adanya ketidaksesuaian antara pertumbuhan rahang dan ukuran gigi.

Kelompok AC yang membutuhkan perawatan borderline dengan nilai 6 dan 7 sebanyak 2 orang $(6,6 \%)$. Pada nilai 6 terlihat adanya deepbite dimana gigi rahang atas hampir menutupi gigi pada rahang bawah, sedangkan pada nilai 7 terlihat deepbite yang parah sehingga gigi anterior rahang bawah tertutup oleh gigi anterior rahang atas. Hal tersebut dapat disebabkan oleh beberapa faktor seperti kebiasaan buruk mengigit bibir bawah. ${ }^{18}$

Kelompok AC kategori sangat butuh perawatan dengan nilai 8 yaitu 1 orang $(3,3 \%)$. Pada nilai 8 terlihat posisi gigi kaninus yang ektopik pada rahang atas dan gigi berjejal pada rahang bawah. Dalam hal ini letak gigi kaninus tumbuh lebih ke atas, di luar lengkung gigi dan menonjol kedepan.

Penilaian DHC secara objektif menunjukkan sebanyak 18 orang $(60 \%)$ tidak atau butuh perawatan ringan. Nilai 1 dan 2 memiliki jumlah yang sama. Untuk nilai 1 mencakup pergeseran jarak kurang $1 \mathrm{~mm}$. Nilai 2 yaitu adanya openbite yang $<1 \mathrm{~mm}$ atau $\geq 2 \mathrm{~mm}$, crossbite $\leq 1 \mathrm{~mm}$, dan memiliki overjet $>3,5 \mathrm{~mm}$ tetapi $\leq 6 \mathrm{~mm}$ dengan bibir yang kompeten. Hal tersebut dapat disebabkan oleh kebiasaan oral seperti menghisap jari dan menjulurkan lidah. 
Kolonio, Anindita, Mintjelungan: Kebutuhan perawatan ortodonsi...

Tabel 3. Distribusi AC pada subjek penelitian.

\begin{tabular}{lccc}
\hline Kebutuhan perawatan ortodonsi & Aesthetic Component & n & $(\boldsymbol{\%})$ \\
\hline Tidak butuh atau butuh & Nilai 1 & 3 & 10 \\
perawatan ringan & Nilai 2 & 5 & 16,7 \\
& Nilai 3 & 15 & 50 \\
& Nilai 4 & 4 & 13,3 \\
Total & & 27 & 90 \\
Borderline & Nilai 5 & 0 & 0 \\
& Nilai 6 & 1 & 3,3 \\
Total & Nilai 7 & 1 & 3,3 \\
Sangat butuh & & 2 & 6,7 \\
& Nilai 8 & 1 & 3,3 \\
Total & Nilai 9 & 0 & 0 \\
& Nilai 10 & 0 & 0 \\
& & 1 & 3,3 \\
\hline
\end{tabular}

Tabel 4. Distribusi DHC pada subjek penelitian

\begin{tabular}{lccc}
\hline Kebutuhan perawatan ortodonsi & $\begin{array}{c}\text { Dental Health } \\
\text { Component }\end{array}$ & $\mathbf{n}$ & $\mathbf{( \% )}$ \\
\hline Tidak butuh atau butuh perawatan ringan & Nilai 1 & 9 & 30 \\
Total & Nilai 2 & 9 & 30 \\
Borderline & & 18 & 60 \\
Total & Nilai 3 & 8 & 26,7 \\
Sangat butuh & & 8 & 26,7 \\
& Nilai 4 & 4 & 13,3 \\
Total & Nilai 5 & 0 & 0 \\
& & 4 & 13,3 \\
\hline
\end{tabular}

Tabel 5. Distribusi AC terhadap DHC

\begin{tabular}{lcccccc}
\hline IOTN & $\begin{array}{c}\text { Tidak butuh atau butuh } \\
\text { perawatan ringan }\end{array}$ & \multicolumn{2}{c}{ Borderline } & \multicolumn{2}{c}{$\begin{array}{c}\text { Sangat butuh } \\
\text { perawatan }\end{array}$} \\
& $\mathrm{n}$ & $\%$ & $\mathrm{n}$ & $\%$ & $\mathrm{n}$ & $\%$ \\
\hline AC & 27 & 90 & 2 & 6,7 & 1 & 3,3 \\
DHC & 18 & 60 & 8 & 26,7 & 4 & 13,3 \\
\hline
\end{tabular}

Kelompok yang membutuhkan perawatan borderline yaitu sebanyak 8 orang $(26,7 \%)$ dengan nilai 3 terlihat adanya openbite posterior $>2 \mathrm{~mm}$. Kelompok yang sangat butuh perawatan merupakan jumlah terkecil yaitu 4 orang $(13,3 \%)$ dengan nilai 4. Hasil DHC yang terkecil yaitu kelompok sangat butuh perawatan merupakan hal yang baik karena hanya sedikit siswa yang sangat butuh perawatan ortodonsi yang berat. Peneliti berasumsi bahwa kondisi tersebut dapat dipengaruhi oleh tingkat kesadaran orang tua dalam mendidik anaknya untuk tidak melakukan kebiasan buruk pada mulut yang dapat menyebabkan maloklusi. Juga letak geografis Wori dengan akses trasportasi lancar sehingga memudahkan siswa/siswi untuk mendapat pelayanan kesehatan dalam hal ini melakukan kunjungan ke dokter gigi. Selain itu informasi juga mudah didapat dari berbagai media.

Nilai AC dan DHC memiliki kesamaan pada pola hasil pemeriksaan, namun tetap memiliki perbedaan persentase nilai antara AC dan DHC. Hal tersebut dikarenakan pemeriksaan AC hanya menilai secara subjektif dengan melihat sisi penampilan dari gigi anterior melalui foto, sedangkan DHC menilai secara objektif dengan 
melakukan pemeriksaan dan pengukuran keadaan gigi. Hal ini menunjukkan bahwa penampilan gigi secara anterior yang menarik atau ideal belum tentu tidak memiliki anomali lainnya. Kondisi yang berbeda justru terjadi pada penilaian DHC yang tidak hanya menilai gigi anterior, tetapi menilai bagian posterior juga.

Kategori yang tidak butuh atau butuh perawatan ringan merupakan kelompok terbanyak yaitu AC 27 orang (90\%) dan DHC 18 orang $(60 \%)$. Kategori yang membutuhkan perawatan borderline yaitu AC $2(6,7 \%)$ dan $8(26,7 \%)$, sedangkan kategori yang paling sedikit yaitu sangat butuh perawatan ortodonsi dengan AC 1 orang $(3,3 \%)$ dan DHC 4 orang $(13,3 \%)$. Hasil ini sesuai dengan penelitian yang dilakukan oleh Manzanera ${ }^{19}$ (2008) pada anak usia remaja di Spanyol yang menyatakan bahwa kategori tidak butuh atau butuh perawatan ringan lebih banyak, dibandingkan dengan perawatan borderline dan sangat butuh perawatan.

\section{SIMPULAN}

Dari hasil penelitian terhadap siswasiswi SMP Negeri 1 Wori dapat disimpulkan bahwa:

1. Berdasarkan Aesthetic component (AC) sebagian besar siswa-siswi terdapat pada kategori tidak butuh perawatan atau butuh perawatan ringan.

2. Berdasarkan Dental Health Component (DHC) lebih dari setengah siswa-siswi terdapat pada kategori tidak butuh perawatan atau butuh perawatan ringan.

\section{SARAN}

1. Berdasarkan hasil penelitian komponen DHC (60\%) berada pada kategori tidak butuh perawatan atau butuh perawatan ringan maka peneliti diharapkan adanya penyuluhan kesehatan gigi dan mulut khususnya mengenai mencegah dan merawat maloklusi.

2. Diharapkan penelitian lebih lanjut mengenai indeks kebutuhan perawatan orthodonti berdasarkan faktor etiologi seperti lingkungan dan sosial ekonomi

\section{DAFTAR PUSTAKA}

1. Nazruddin. Peranan ortodonsi pada perawatan kelainan susunan gigi geligi yang tidak teratur [Skripsi]. Medan; Universitas Sumatera Utara; 2008.

2. Dewi O. Analisis hubungan maloklusi dengan kualitas hidup remaja SMU Kota Medan 2007 [Tesis] (tidak dipublikasikan). Medan: Fakultas Kedokteran Gigi Universitas Sumatra Utara; 2010.

3. Buckley LA. The relationship between malocclusion, gingival inflammation, plaque and calculus. J Periodontol. 1981;52(1):35-40.

4. Shaw WC, Addy M, Ray C. Dental and social effects of malocclusion and effectiveness of orthodontic treatment; a review. Community Dent Oral Epidemiol. 1980;8(1):3645.

5. Brook PH, Shaw WC. The development of an index of orthodontic treatment priority. Eur J Orthod. 2009;11(3):309-20.

6. Dika D, Hamid T, Sylvia M. Penggunaan index of orthodontic treatment need (iont) sebagai evaluasi hasil perawatan dengan piranti lepasan. Ortho Dent J. 2011;1:12-7.

7. Pakpahan EL, Hoesin F, Krisnawati. Kebutuhan perawatan ortodonti remaja SLTP usia 12-13 tahun di Jakarta Selatan. Jurnal Kedokteran Gigi. 2005;17(2):41-9.

8. Emmadita. Gambaran tingkat kebutuhan perawatan ortodontik berdasarkan index of orthodontic treatment need pada anak usia 11-12 tahun di SDK 6 BPK Penabur Bandung [Skripsi]. Bandung: Fakultas Kedokteran Gigi Universitas Maranatha; 2011.

9. Putri W. Krisnawati. Nada I. Gambaran maloklusi dan kebutuhan perawatan ortodonti pada usia 9-11 tahun di SD At-Taufiq. Jurnal PDGI. 2014; 63(1):25-9.

10. Musyulianti. Kebutuhan perawatan ortondonsi pada SMP Eben Heazer 1 Manado [Skripsi]. Manado: Program Studi Kedokteran Gigi Fakultas Kedokteran Universitas Sam Ratulangi; 2010.

11. Endang S. Kebutuhan perawatan ortodonsi 
pada SMA Kecamatan Malalayang Manado [Skripsi]. Manado: Program Studi Kedoteran Gigi Fakultas Kedokteran Universitas Sam Ratulangi; 2011.

12. Monica R. Kebutuhan perawatan ortodonsi berdasarkan index of orthodontic treatment need pada siswa kelas 2 di sekolah menengah pertama Negeri 2 Bitung [Skripsi]. Manado: Program Studi Kedokteran Gigi Fakultas Kedokteran Universitas Sam Ratulangi; 2014.

13. Franzoi SL. Social Psychology (3rd ed). Boston: Mc Graw Hill, 2003; p. 1724.

14. Atashi MHA. Prevalence of malocclusion in 13-15 year-old adolescents in Tabriz. JODDD. 2007;1(1):14.

15. Wijaknarko AG. Prevalensi maloklusi pada remaja usia 12-14 tahun pada Sekolah Menengah Pertama di
Jakarta [Tesis]. Jakarta: FKG UI; 1999.

16. Wilar A. Kebutuhan perawatan ortodonsi berdasarkan index of orthodontic treatment need pada siswa di Sekolah Menengah Pertama Negeri 1 Tareran [Skripsi]. Manado: Program Studi Kedokteran Gigi Fakultas Kedokteran Universitas Sam Ratulangi; 2014.

17. Harshnur WI. Anatomi Gigi. Jakarta: EGC, 2012; p. 214.

18. Mitchell L. The etilogy of malocclusion. In: Introduction of Orthodontics (3rd ed). Oxford: Oxford University Press, 2012; p. 10-11.

19. Manzanera D, Company JM, Silla JM, Gandia JL. Orthodontic treatment need in Spanish scoolchildren: an epidemiological study using the Index of Orthodontic Treatment Need. Eur J Orthod. 2009;31(2):180-3. 